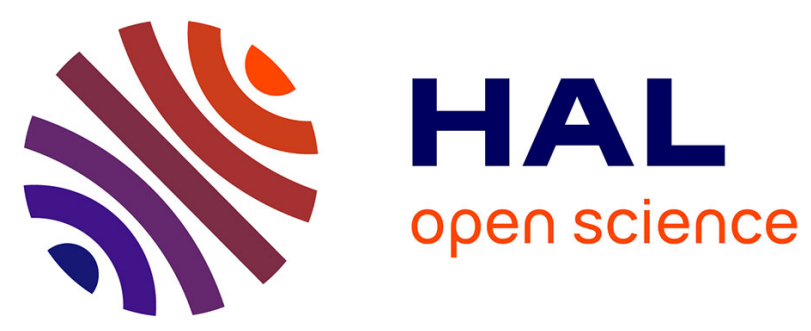

\title{
Olive mill waste and glyphosate-based herbicide addition to olive grove soils: effects on microbial activities and their responses to drying-rewetting cycles
}

Nathalie Boukhdoud, Anne Marie Farnet da Silva, T. Darwish, R Gros

\section{- To cite this version:}

Nathalie Boukhdoud, Anne Marie Farnet da Silva, T. Darwish, R Gros. Olive mill waste and glyphosate-based herbicide addition to olive grove soils: effects on microbial activities and their responses to drying-rewetting cycles. Soil Use and Management, 2017, 33 (3), pp.499 - 510. 10.1111/sum.12367 . hal-01783095

\section{HAL Id: hal-01783095 \\ https://hal-amu.archives-ouvertes.fr/hal-01783095}

Submitted on 2 May 2018

HAL is a multi-disciplinary open access archive for the deposit and dissemination of scientific research documents, whether they are published or not. The documents may come from teaching and research institutions in France or abroad, or from public or private research centers.
L'archive ouverte pluridisciplinaire HAL, est destinée au dépôt et à la diffusion de documents scientifiques de niveau recherche, publiés ou non, émanant des établissements d'enseignement et de recherche français ou étrangers, des laboratoires publics ou privés. 


\title{
Olive mill waste and glyphosate-based herbicide addition to olive grove soils: effects on microbial activities and their responses to drying-rewetting cycles
}

\author{
N. Boukhdoud ${ }^{1,2}$, A. M. Farnet Da Silva $^{1}$, T. Darwish ${ }^{2} \&$ R. Gros ${ }^{1}$ id \\ ${ }^{1}$ Institut Méditerranéen de Biodiversité et d'Ecologie marine et continentale (IMBE), Aix Marseille Université, CNRS, IRD, \\ Avignon Université, Campus l'Etoile, Av. Escadrille Normandie Niemen, 13397 Marseille, Cedex 20, France, and ${ }^{2}$ Center for \\ Remote Sensing (CNRS-Liban), Beirut, Lebanon
}

\begin{abstract}
The objective of this experimental study was to determine the effect of agronomic practices usually implemented in olive groves (addition of olive mill waste and herbicides) on soil microbial communities and to test whether drought enhanced such effects. For that purpose, mesocosms containing soil cores from olive groves were incubated for 5 months under either of the three treatments: (i) addition of olive mill waste (OMW), (ii) addition of glyphosate-based herbicide (Gly treatment) and (iii) both treatments. Half of the mesocosms were subjected or not (controls) to drying-rewetting cycles $(\mathrm{D} / \mathrm{Rw})$ for 1 month $(1 \mathrm{D} / \mathrm{Rw})$ or 3 months $(3 \mathrm{D} / \mathrm{Rw})$. In the controls, 2 months after the Gly treatment, higher lipase activities were observed compared with no practice treatment as well as a significant change in catabolic profiles of cultivable microbial communities. Three months later, lipase activities significantly decreased under the Gly treatment. Addition of OMW together with Gly treatment counteracted the negative effect of the herbicide on lipase activities. After three D/Rw cycles, Gly treatment modified catabolic profiles and induced a decrease in functional diversity. Overall, the combination of glyphosate-based herbicide with OMW was a conservative practice that maintained soil functioning and led to a better response to $\mathrm{D} / \mathrm{Rw}$ cycles.
\end{abstract}

Keywords: Olive mill wastes, herbicide, drying-rewetting cycles, soil quality, microbial activities, Olea europaea

\section{Introduction}

The Mediterranean region is subject to natural constraints such as low soil organic matter content, hot dry summers, and both low fertility and productivity (Sofo et al., 2008). Climate projections for the coming decades have predicted an increase in mean annual temperatures (IPCC 2014) and drought periods (hydric stress) in this region, which is considered to be particularly sensitive to these expected stressful conditions (Giorgi \& Lionello, 2008). In this respect, herbicide addition may help to decrease water competition between olive trees and weeds.

Olive mill wastes are generated in huge quantities (more than 30 million $\mathrm{m}^{3}$ per year) from the olive oil sector and applied to olive grove soils as organic fertilizers (Doula et al., 2017). These wastes are both solid, known as

Correspondence: R. Gros. E-mail: raphael.gros@imbe.fr Received December 2016; accepted after revision July 2017 pomace, and liquid, known as olive mill wastewater. The solid pomace contains the skins, pulp, seeds and stems of the fruit and is rich in nutrients especially carbon (C) and potassium $(\mathrm{K})$ but also nitrogen $(\mathrm{N})$ and phosphorous $(\mathrm{P})$ (Peri \& Proietti, 2014). There are two types derived from three-phase and two-phase processes. Furthermore, wastewaters are characterized by the presence of organic compounds (especially polymeric phenolic compounds with considerable antimicrobial and phytotoxic activity), high content of salts, which can lead to a slight acidification of soils and an imbalanced $\mathrm{C} / \mathrm{N}$ ratio (Peri \& Proietti, 2014). However, the addition of this olive mill waste (OMW) may also, due to its organic matter content, improve soil aggregation, thus also improving soil porosity, water retention capacity and nutrient contents (Regni et al., 2017). Therefore, improving the current knowledge on the consequences of such practices on soil physicochemical properties and microbial activities is necessary to sustain soil quality under exacerbated climatic stresses. 
Traditionally, olive grove management was mainly based on tillage, which drastically alters the top layer of the soil. In non-tillage agriculture, herbicides are commonly used to control weeds and reduce both nutrient and water competition, although they may cause harmful effects on the environment by altering soil fauna (Gaupp-Berghausen et al., 2015) and below-ground interactions between essential soil organisms such as earthworms and arbuscular mycorrhizal fungi (Zaller et al., 2014). The effect of glyphosate (N-(phosphonomethyl)glycine) on soil microbial communities has been extensively studied and contrasting results have been reported depending on the dose of glyphosate applied onto the soil and its frequency (Lane et al., 2012; Nguyen et al., 2016). For instance, studies have indicated that soil microorganisms could use glyphosate as a source of $\mathrm{C}$ leading to an increase in soil microbial biomass, basal respiration and $\mathrm{N}$ mineralization (Haney et al., 2002). Other studies have reported a decrease in soil microbial activities and biomass, and a shift in fungi/bacteria ratios when glyphosate was applied in vitro (Lane et al., 2012).

In contrast, addition of solid or liquid OMW onto soil is used as an alternative soil management practice to improve soil structure, increase soil fertility and control soil erosion (Lozano-García et al., 2011; Regni et al., 2017). Due to their high organic matter content, these wastes can increase soil microbial respiration and some enzyme activities (Mekki et al., 2006). As well as positive effects, they may also cause harmful effects such as the decrease in microbial biomass carbon (Di Bene et al., 2013), and bacterial phylogenetic richness and diversity (Siles et al., 2014). Moreover, Proietti et al. (2015) found few modifications in the amount of different bacterial groups after 3 years of OMW amendment in olive groves. In both the upper and lower soil layers, the total counts of viable bacteria and bacterial spores were either unchanged or slightly higher in the treated soil than in the control. Interestingly, the culture-independent evaluation of the relative variation in bacterial amount with respect to the control soil, carried out by qPCR analysis of 16S rRNA genes, indicated that treatment with OMW did not lead to significant modifications. The applied dose of OMW has been regulated in many European countries in order to maintain the positive effects on soil function (Tsiknia et al., 2014).

In this study, we used a mesocosm-scale experiment to evaluate (i) the effect of glyphosate-based herbicide addition, OMW amendment and the combination of both on soil microbial activities and (ii) the responses of microbial communities to 1 or 3 drying-rewetting cycles applied to these treatments. We hypothesized that addition of both OMW and herbicide could have non-additive synergistic effects on soil microbial activities and catabolic diversity. We also expected that a shift in functional diversity of microbial communities after OMW or herbicide addition may lead to different functional responses to drying-rewetting cycles mimicking climate stresses.

\section{Material and methods}

\section{Experimental set-up}

Four abandoned olive groves (1 ha each), at least $20 \mathrm{~km}$ distant from each other, were selected in the regional natural park of Alpilles, near the city of Marseille (southeastern France). No agricultural practice had been applied for approximately the last 20 years. The olive trees belonged to the same variety (i.e. 'aglandau') and had a similar age range (i.e. $40 \pm 5$ years). In the centre of each grove, a sampling site of $400 \mathrm{~m}^{2}$ was delimited and 17 soil cores (Calcaric Cambisol) were sampled along with the plant cover in November 2013 using PVC cylinders $(10 \mathrm{~cm}$ diameter $\times$ $10 \mathrm{~cm}$ deep). The cores were forced into the soil using a hammer, and sampled at a distance of $1 \mathrm{~m}$ from the tree trunk in order to avoid the sampling of olive roots. Cores were left inside the PVC cylinders to maintain soil structure. Four of the 68 soil cores (one from each site) were immediately analysed to determine initial chemical properties (Table 1).

The remaining 64 soil cores were maintained at $60 \%$ of water-holding capacity [i.e. watered twice a week with distilled water at $\mathrm{pH} 6$ and weighed to keep a constant water-holding capacity (WHC)] for 1 month at $18 \pm 2{ }^{\circ} \mathrm{C}$ to ensure favourable initial conditions for microbial activity and to avoid effects resulting from humidity variations between sampling plots (Figure 1). After the pre-incubation month, the four following treatments were applied to four soil cores from each site (Figure 1). Sixteen cores were left without treatment ('no practice'), 16 cores (Gly treatment) received $20 \mathrm{~mL}$ of a commercial glyphosate-based solution ROUNDUP (7.2 g/L) diluted 20 times, which corresponded to an application of approximately $2 \mathrm{mg}$ of glyphosate per $\mathrm{kg}$ of soil (Araújo et al., 2003; Nguyen et al., 2016), and 16

Table 1 Main initial chemical properties (mean \pm standard deviation, $n=4$ ) of soils and of the applied OMW

\begin{tabular}{lcr}
\hline & Soil & OMW \\
\hline Organic C (\%) & $4.0 \pm 2.18$ & 56.43 \\
Total N (\%) & $0.32 \pm 0.21$ & 1.38 \\
C/N ratio & $15.61 \pm 10.16$ & 40.89 \\
CaCO3 (\%) & $31.85 \pm 8.41$ & - \\
pH in water & $7.44 \pm 0.34$ & 6.94 \\
Alkyl C (\%) & $29.60 \pm 10.22$ & 17.13 \\
O-Alkyl C (\%) & $43.34 \pm 11.96$ & 61.94 \\
Carboxyl C (\%) & $10.49 \pm 0.63$ & 7.39 \\
Aromatic C (\%) & $16.57 \pm 4.15$ & 13.54 \\
Aromatic ratio & $0.19 \pm 0.045$ & 0.15 \\
HR $_{1}$ & $0.77 \pm 0.43$ & 0.28 \\
HR $_{2}$ & $2.85 \pm 1.09$ & 2.31 \\
\hline
\end{tabular}

$\mathrm{HR}_{1}$ and $\mathrm{HR}_{2}$ : Humification ratios (see Material and methods section) 

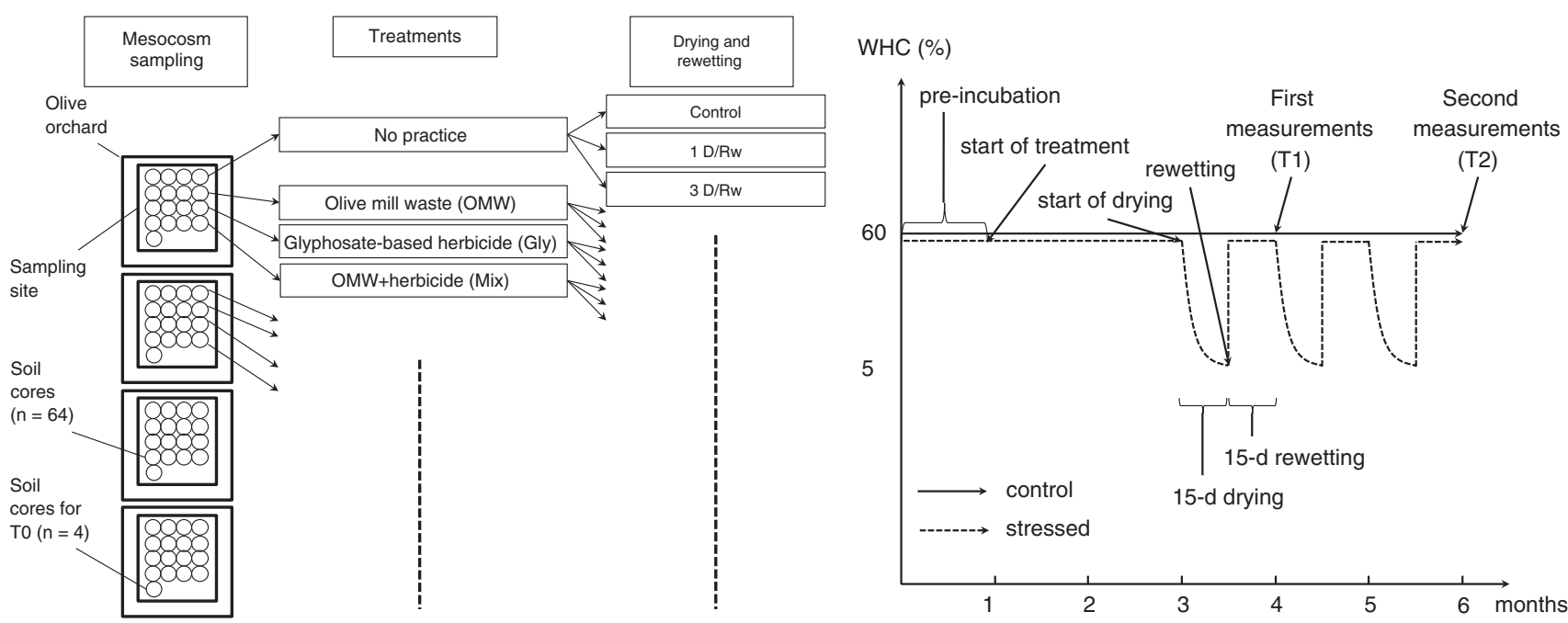

Figure 1 A schematic diagram illustrating the experimental set-up (not to scale).

other cores (OMW treatment) were amended with $46.8 \mathrm{~g}$ of olive mill wastes mixed in $80 \mathrm{~mL}$ of distilled water corresponding to an application of approximately $60 \mathrm{t} / \mathrm{ha}$ (Tsiknia et al., 2014). The main chemical properties of the applied OMW are given in Table 1. Finally, a last batch of 16 cores ('Mix' treatment) was used to test the effects of a combination of glyphosate-based herbicide and OMW with the same applied quantities as above.

For each treatment, half of the cores from a site were subjected to control conditions of moisture and temperature, while the other half were subjected to $\mathrm{D} / \mathrm{Rw}$ cycles which corresponded to stressed conditions (Figure 1). For control conditions, cores were maintained at $60 \%$ of WHC and at a temperature of $18 \pm 2{ }^{\circ} \mathrm{C}$ for 5 months. For the stressed conditions, we firstly maintained cores in these optimal conditions for 2 months, and then three $\mathrm{D} / \mathrm{Rw}$ cycles were applied. Each $\mathrm{D} / \mathrm{Rw}$ cycle was composed of two steps: (i) a drying period of 15 days at $30{ }^{\circ} \mathrm{C}$ to reach a final water content of $<5 \%$ WHC and (ii) a rewetting period of 15 days with a fast recovery of moisture to $60 \%$ WHC at $18{ }^{\circ} \mathrm{C}$.

The chemical and microbial properties described below were measured 3 months (T1) and 5 months (T2) after the treatments were applied (Figure 1).

\section{Chemical properties of soils}

Soil $\mathrm{pH}$ was assessed by a soil (2 $\mathrm{mm}$ mesh)-water suspension $(1 / 2.5) 2 \mathrm{~h}$ after shaking. Soil total organic carbon (TOC) and total nitrogen (TN) content were measured on air-dried samples using a $\mathrm{C} / \mathrm{N}$ elemental analyser (Flash EA 1112 series Thermo Scientific). Determination of calcium carbonate $\left(\mathrm{CaCO}_{3}\right)$ in soils was based on the release of $\mathrm{CO}_{2}$ after addition of $\mathrm{HCl} 4 \mathrm{~N}$. The percentage of carbon in $\mathrm{CaCO}_{3}$ was calculated as follows:
$\mathrm{C}-\mathrm{CaCO}_{3}=11.991 / 100.1 \times \mathrm{CaCO}_{3}$. Organic carbon was calculated as the difference between TOC and carbonate $\mathrm{C}$ content.

The quality of organic matter was determined by solidstate nuclear magnetic resonance (NMR) of ${ }^{13} \mathrm{C}$ and spectra were obtained on a Bruker Avance 400-MHz NMR spectrometer operating at a ${ }^{13} \mathrm{C}$ resonance frequency of $106 \mathrm{MHz}$ and using a Bruker double-bearing probe. The ${ }^{13} \mathrm{C}$ NMR spectra, obtained from samples of $400 \mathrm{mg}$ of dry ground soil spun at a magic angle spinning (MAS) rate of $10 \mathrm{kHz}$, were divided into four chemical shift regions: alkyl C (0-45 ppm), O-alkyl C (45-112 ppm), aromatic C (112$160 \mathrm{ppm}$ ) and carboxyl C (160-185 ppm) (Baldock et al., 1992). Two ratios were calculated from the $\mathrm{NMR}{ }^{13} \mathrm{C}$ data: the aromaticity ratio (the sum of aromatic $\mathrm{C}$ to the sum of all regions except carboxyl $\mathrm{C}$ ) and the humification ratios $\mathrm{HR}_{1}$ (Alkyl C to Carboxyl C) and $\mathrm{HR}_{2}$ (alkyl C to O-alkyl C).

\section{Enzyme activities, basal respiration and microbial biomass}

Five enzyme activities were quantified directly in fresh soils and expressed as $\mu$ moles of the reaction product released per $\mathrm{h}$ per $\mathrm{g}$ of soil equivalent dry weight $(\mathrm{U} / \mathrm{g})$. Lipase, protease, urease, cellulase and tyrosinase activities were chosen because they are the main activities involved in the turnover of the $\mathrm{C}$ and $\mathrm{N}$ cycles. The applied treatments provide nutrients, lipids, polyphenols and other components to soils which may induce such activities.

Cellulases were assessed using carboxy methyl cellulose (CMC) at $1 \%$ as substrate. The glucose released was quantified using the Somogyi-Nelson method modified by Farnet et al. (2010b). Tyrosinase activity, based on the oxidation of tyrosine to L-Dopa $(\varepsilon=3400 \mathrm{~L} / \mathrm{mol} / \mathrm{cm})$, was performed using a modified method of Saiya-Cork et al. 
(2002). Urease activity was measured as described by Kandeler \& Gerber (1988) based on the determination of $\mathrm{NH}_{4}{ }^{+}$after urea hydrolysis. Protease activity was determined using the method of Ladd \& Butler (1972). Lipase activity was measured according to Farnet et al. (2010a) using p-nitrophenyl (pNP) laurate as a substrate.

Basal respiration (BR) and microbial biomass (MB) were assessed after humidity standardization of all soil samples at $60 \%$ WHC. For BR, an aliquot of $10 \mathrm{~g}$ (dry weight equivalent) of fresh soil was placed in glass jars $(117 \mathrm{~mL})$, flushed with fresh air and closed by rubber septum before incubation at $25{ }^{\circ} \mathrm{C}$ for $4 \mathrm{~h}$. After incubation, $1 \mathrm{~mL}$ of air was sampled in the head space with a syringe and injected into a gas chromatograph (Chrompack CHROM3-CP 9001) to analyse $\mathrm{CO}_{2}$ production. $\mathrm{MB}$ was estimated using substrate-induced respiration (SIR) rates (Anderson \& Domsch, 1978). Induced respiration rates by glucose were converted into microbial biomass using equations given by Beare et al. (1990). The metabolic quotient $\mathrm{qCO}_{2}$ is the ratio of BR to MB.

\section{C-substrate utilization profiles and catabolic diversity}

The community-level physiological profiles (CLPPs) and catabolic diversity (CD) were determined with BIOLOG $^{\circledR}$ EcoPlates (BIOLOG Inc., Hayward, CA, USA) using a procedure adapted from Garland \& Mills (1991). We purposely did not adjust the inoculum as we considered the total microbial number as an inherent characteristic of microbial communities of each plot. Microbial C-use intensity was assessed as the rate of average well colour development (AWCD) calculated as follows (equation 1):

$$
\mathrm{AWCD}=\frac{\sum \mathrm{ODi}}{31}
$$

where ODi is the optical density for each well in the mid-exponential growth phase (i.e. after $72 \mathrm{~h}$ ). The incubation time resulting in an AWCD equal to 0.5 absorbance units (T0.5) was calculated for each sample and used to standardize the optical density of each C-containing well (Garland \& Mills, 1991). CD was calculated using Shannon's diversity index (equation 2):

$$
\mathrm{H}=-\sum p i(\ln p i)
$$

where pi is the ratio of colour development of well $i$ to the sum of colour development of all positive wells.

\section{Statistical analyses}

Two-way repeated-measures ANOVAs were used to determine the effects of treatments and of conditions (control vs. stressed) across time (3 and 5 months) on soil chemical and microbial properties. We used the HSD Tukey's test $(P<0.05)$ to analyse in detail the variations between each treatment. Data were $\log 10$-transformed when necessary to meet the assumption of normality. These analyses were performed using Statistica 6.0.

A principal component analysis (PCA) was performed on the covariance matrix obtained from $\mathrm{BIOLOG}^{\circledR}$ data using Primer software v6 (Primer-E Ltd, UK). The PCA provided an ordination of the microbial C-substrate utilization profiles, which were plotted in one and two dimensions, respectively, based on the scores of the first two principal components (PC). Effects of treatments and conditions for each time were tested by main and pairwise tests in PERMANOVA using Primer software v6 (Primer-E Ltd).

We assessed the non-additive effect of the combination of both Gly and OMW treatments by comparing microbial activities to a null-model based on the average (predicted values) of the Gly and OMW activities that made up the combination (observed values). The relative combination effect (RCE) can be calculated as follows (equation 3):

$$
\mathrm{RCE}=\frac{[(\text { observed }- \text { predicted })]}{\text { predicted }} \times 100
$$

If RCE differs from zero (one-sample Student's $t$-tests with $95 \%$ confidence intervals), it will indicate a non-additive effect. Significant negative and positive deviations from zero are referred to as antagonistic and synergistic effects, respectively.

\section{Results}

\section{Soil chemical properties}

The quality of organic matter, assessed by all the studied ${ }^{13} \mathrm{C}$ NMR signals and ratios, was not affected by treatment or by time. However, the quantity of organic matter determined by $\mathrm{TN}$ content, TOC content and $\mathrm{C} / \mathrm{N}$ ratio decreased with time $(P<0.05, P<0.01, P<0.05$, respectively) whatever the treatment. Soil $\mathrm{pH}$ was controlled by a significant interaction between both time and treatments $(P<0.05)$ with a main effect of time $(P<0.01)$. At T1 $(3$ months after the beginning of the treatment), soil $\mathrm{pH}$ was lower under the Mix treatment compared with the other treatments (Figure 2). Soil $\mathrm{pH}$ decreased between $\mathrm{T} 1$ and $\mathrm{T} 2$ for all treatments except for the Mix treatment.

\section{Soil microbial activity}

While five of the tested microbial markers (basal respiration, urease activity, protease activity, cellulase activity and tyrosinase activity) were affected by time, lipase activity and CD index remained unaffected (Table 2). Both basal respiration and lipase activity were found to vary depending 


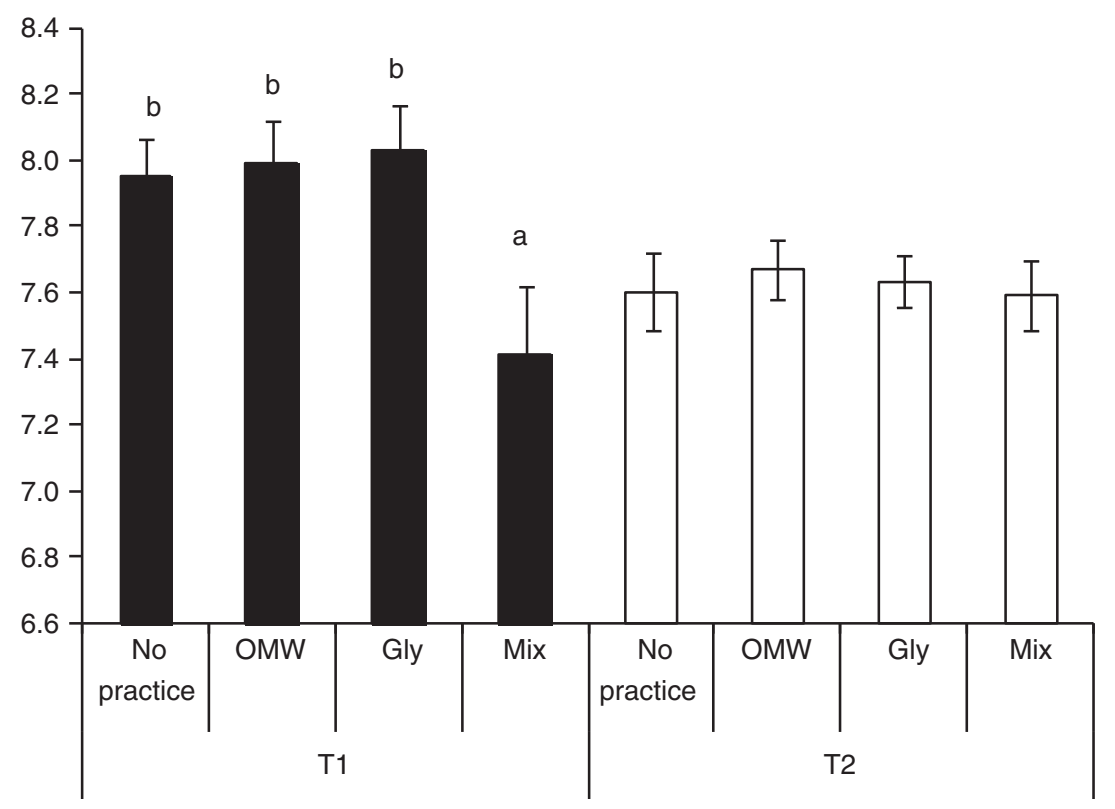

Figure 2 Mean soil $\mathrm{pH}$ ( \pm standard deviation, $n=4) 3$ months (T1) (black bars) and 5 months (T2) (white bars) after the addition of olive mill waste (OMW), glyphosate-based herbicide (Gly), combination of both (Mix) and no practice. Different lowercase letters represent significant differences $(P<0.05)$ between treatments at $\mathrm{T} 1$.

Table 2 Results of repeated-measures ANOVAs with treatments as between-subject factor and time as within-subject factor on soil microbial markers

\begin{tabular}{|c|c|c|c|}
\hline & \multirow{2}{*}{$\begin{array}{c}\text { Between } \\
\text { subjects } \\
\text { Treatment }\end{array}$} & \multicolumn{2}{|c|}{ Within subjects } \\
\hline & & Time & Time $\times$ Treatment \\
\hline $\begin{array}{l}\text { Degree of freedom } \\
\text { (Df) }\end{array}$ & 3 & 1 & 3 \\
\hline $\begin{array}{l}\text { Basal respiration } \\
\left(\mu \mathrm{g} \mathrm{C}-\mathrm{CO}_{2} / \mathrm{g}\right)\end{array}$ & $0.47 \mathrm{NS}$ & $72.40^{* * *}$ & $4.57 *$ \\
\hline $\begin{array}{l}\text { Microbial biomass } \\
(\mu \mathrm{g} \mathrm{Cmic/g})\end{array}$ & $0.58 \mathrm{NS}$ & $10.09 *$ & $0.86 \mathrm{NS}$ \\
\hline Metabolic quotient & $0.65 \mathrm{NS}$ & $6.29^{*}$ & $0.86 \mathrm{NS}$ \\
\hline $\begin{array}{l}\text { Tyrosinase activity } \\
(\mathrm{U} / \mathrm{g})\end{array}$ & $0.63 \mathrm{NS}$ & $985.40 * * *$ & $0.63 \mathrm{NS}$ \\
\hline $\begin{array}{l}\text { Cellulase activity } \\
(\mathrm{U} / \mathrm{g})\end{array}$ & $0.19 \mathrm{NS}$ & $33.47^{* * *}$ & $0.11 \mathrm{NS}$ \\
\hline $\begin{array}{l}\text { Protease activity } \\
(\mathrm{U} / \mathrm{g})\end{array}$ & $1.35 \mathrm{NS}$ & $45.24 * * *$ & $1.04 \mathrm{NS}$ \\
\hline $\begin{array}{l}\text { Lipase activity } \\
(\mathrm{U} / \mathrm{g})\end{array}$ & $5.84 *$ & $1.17 \mathrm{NS}$ & $6.35^{*}$ \\
\hline $\begin{array}{l}\text { Urease activity } \\
(\mathrm{U} / \mathrm{g})\end{array}$ & $0.76 \mathrm{NS}$ & $118.15^{* * *}$ & $0.95 \mathrm{NS}$ \\
\hline $\begin{array}{l}\text { Catabolic diversity } \\
\text { (Shannon) index } \\
\text { (bits) }\end{array}$ & $2.61 \mathrm{NS}$ & $24710.71 \mathrm{NS}$ & $0.06 \mathrm{NS}$ \\
\hline
\end{tabular}

on significant interactions between time and treatment (Table 2). Basal respiration decreased over time for both the no practice and Mix treatments (Figure 3a). Lipase activity was higher on the Gly treatment compared with no practice at $\mathrm{T}$ 1, while the reverse trend was observed at T2 (Figure 3b): under Gly treatment, lipase activity decreased over time. Lipase activity was significantly higher on the Mix treatment than in both Gly and OMW treatments at T2. This could be related to the relative combination effect ratio which showed a significant synergistic non-additive effect on Mix treatment only for lipase activity at T2 $(+885.7 \%$; $P<0.05)$.

The factorial map from PCA (Figure 4) showed a significant discrimination on PC1 $(32.4 \%)$ between $\mathrm{T} 1$ and T2 for both no practice and Mix treatments. Projections of Gly treatment were discriminated from the other projections at T1, according to $\mathrm{PC} 2(16.8 \%)$ and at $\mathrm{T} 2$ according to PC1 $(32.4 \%)$ from projections of the no practice and Mix treatments (positive part of $\mathrm{PC} 1$ axis).

A significant effect of $\mathrm{D} / \mathrm{Rw}$ cycles was observed on tyrosinase and protease activities depending on time (Table 3). At T1, both activities were decreased after the first $\mathrm{D} / \mathrm{Rw}$ cycle but independently of the applied treatment (Figure $5 \mathrm{a}$ and $\mathrm{c}$ ). At $\mathrm{T} 2$, although two additional $\mathrm{D} / \mathrm{Rw}$ cycles had been applied, no difference was observed for these enzyme activities between control and stressed conditions

NS, nonsignificant. ${ }^{*} P<0.05 ; * * * P<0.001$. 

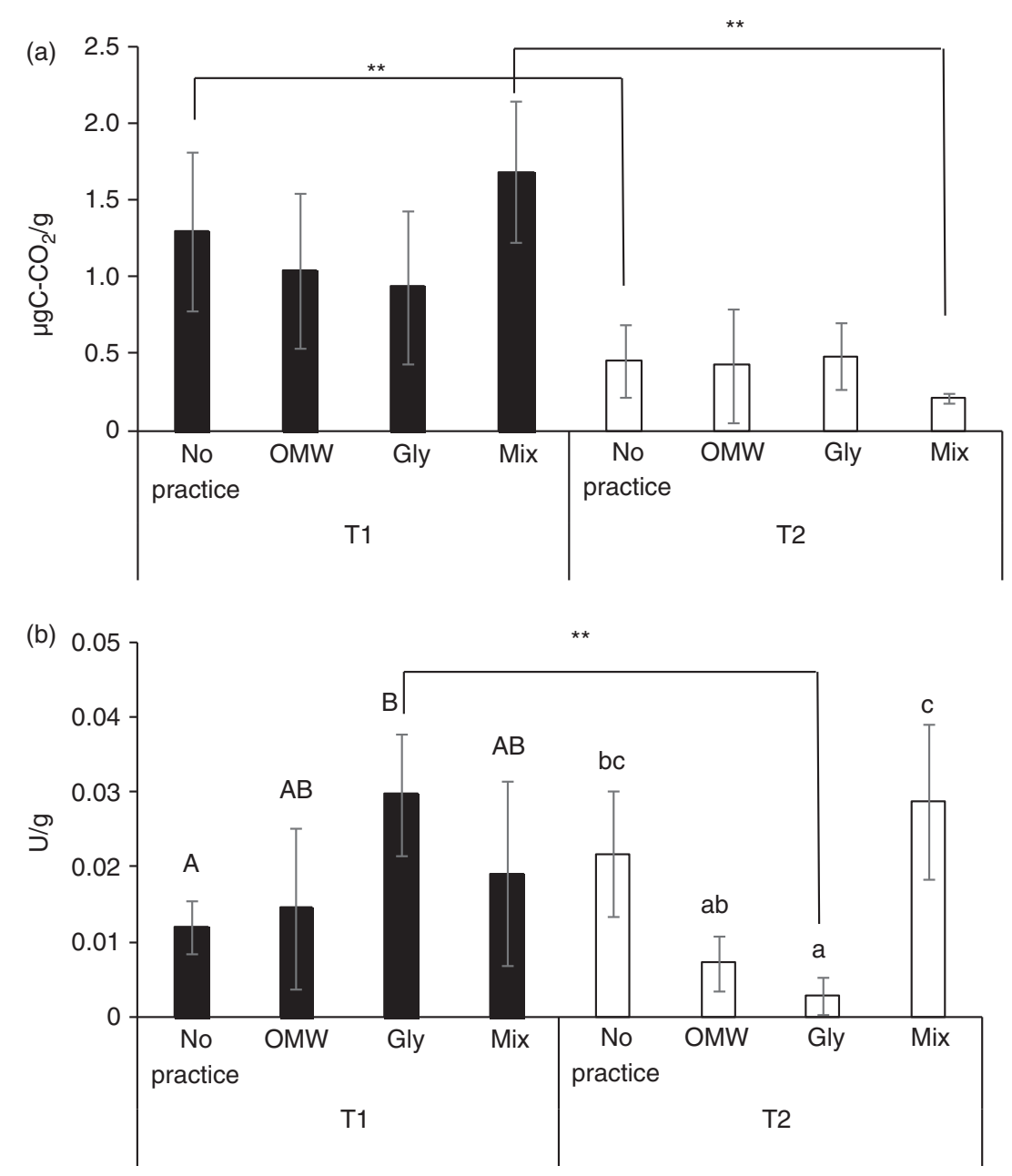

Figure 3 Mean ( \pm standard error, $n=4$ ) basal respiration (a) and lipases (b) after treatments (no practice, OMW, Gly and Mix) for both T1 (black bars) and T2 (white bars). For basal respiration, ** indicates significant differences $(P<0.05)$ between T1 and T2 while for lipases different uppercase or lowercase letters indicate significant differences between treatments at T1 and T2, respectively.

(Figure $5 b$ and d). Except for lipase activities, all enzyme activities, microbial biomass and metabolic quotient varied with time whatever the conditions (Table 3) and more precisely these microbial markers decreased through time (data not shown). Basal respiration (BR) was also affected by $\mathrm{D} / \mathrm{Rw}$ cycles depending on time and treatments (Table 3 ). At $\mathrm{T} 1$, no significant effect of the first $\mathrm{D} / \mathrm{Rw}$ cycle was observed (Figure 5e) while a significant decrease of BR was measured between $\mathrm{T} 1$ and $\mathrm{T} 2$ for OMW after three $\mathrm{D} / \mathrm{RW}$ cycles. However, the combination of OMW and glyphosatebased herbicide maintained the same BR under stressed conditions between T1 and T2 (Figure 5e and f).

\section{Community-level physiological profiles (CLPPS)}

A significant difference in $\mathrm{CD}$ index was observed for the Gly treatment between $\mathrm{T} 1$ and $\mathrm{T} 2$ under stressed conditions, which was not the case under non-stressed conditions
(Figure $5 \mathrm{~g}$ and $\mathrm{h}$ ). This result revealed a decrease in $\mathrm{CD}$ index after $3 \mathrm{D} / \mathrm{Rw}$ cycles on the Gly treatment.

A PERMANOVA test showed a significant difference $(P<0.05)$ for the Gly treatment between control and stressed conditions. To focus on this effect, we performed a PCA on catabolic profiles only considering the no practice and Gly treatments for both conditions at $\mathrm{T} 1$ and T2 (Figure 6). This PCA provided an ordination of microbial carbon utilization patterns plotted on the first two PCs, which accounted for $46.5 \%$ of the total variance. No difference between $\mathrm{T} 1$ and $\mathrm{T} 2$ was observed for the no practice and Gly treatments $(P<0.05)$. The PCA mainly showed a significant $(P<0.05)$ discrimination on $\mathrm{PC} 2$ between control and stressed conditions for Gly treatment. This result revealed that $3 \mathrm{D} / \mathrm{Rw}$ cycles modified microbial CLPPs only for the Gly treatment compared with control conditions. Soils amended with glyphosate-based herbicide and incubated under control conditions were highly and 


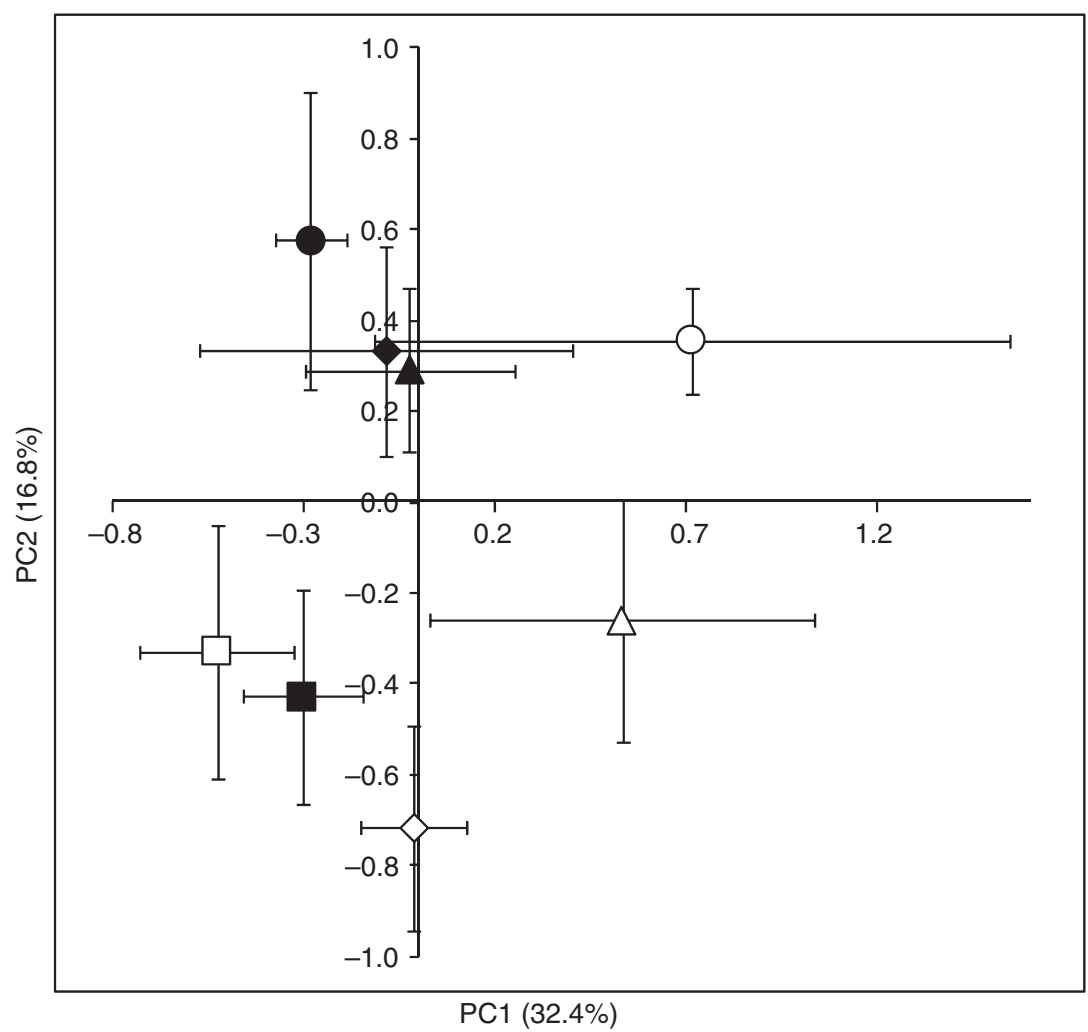

Figure 4 Factorial map $(\mathrm{PC} 1 \times \mathrm{PC} 2)$ obtained from principal component analysis on microbial C-substrate utilization profiles of no practice (circles), olive mill waste (diamonds), glyphosate-based herbicide (squares) and Mix (triangles) treatments at T1 (black symbols) and ־ 2 (white symbols).

Table 3 Results of repeated-measures ANOVAs with treatments and stress as between-subject factors and time as the within-subject factor on soil microbial markers

\begin{tabular}{|c|c|c|c|c|c|c|c|c|c|c|}
\hline Source & Df & Tyrosinases & Proteases & Lipases & Ureases & Cellulases & $\begin{array}{c}\text { Basal } \\
\text { respiration }\end{array}$ & $\begin{array}{c}\text { Microbial } \\
\text { biomass }\end{array}$ & $\begin{array}{c}\text { Metabolic } \\
\text { quotient }\end{array}$ & $\begin{array}{c}\text { Diversity } \\
\text { index }\end{array}$ \\
\hline \multicolumn{11}{|c|}{ Between subject } \\
\hline $\begin{array}{l}\text { Treatment } \\
\text { (TR) }\end{array}$ & 3 & $0.49 \mathrm{NS}$ & $1.68 \mathrm{NS}$ & $3.49 *$ & $1.09 \mathrm{NS}$ & $0.88 \mathrm{NS}$ & $0.81 \mathrm{NS}$ & $0.98 \mathrm{NS}$ & $0.78 \mathrm{NS}$ & $0.49 \mathrm{NS}$ \\
\hline $\begin{array}{l}\text { Condition } \\
\text { (C) }\end{array}$ & 1 & $11.50 * * *$ & $14.78 * * *$ & $2.02 \mathrm{NS}$ & $0.071 \mathrm{NS}$ & $0.68 \mathrm{NS}$ & $4.70^{*}$ & $0.0041 \mathrm{NS}$ & $1.83 \mathrm{NS}$ & $0.22 \mathrm{NS}$ \\
\hline \multicolumn{11}{|l|}{ Within subject } \\
\hline Time $(t)$ & 1 & $1306.65^{* * *}$ & $39.08 * * *$ & $0.88 \mathrm{NS}$ & $228.07 * * *$ & $64.05^{* * *}$ & $55.28 * * *$ & $16.49 * * *$ & $13.51 * * *$ & $10.71 * *$ \\
\hline$t^{*}$ Treatment & 3 & $0.49 \mathrm{NS}$ & $1.45 \mathrm{NS}$ & $1.49 \mathrm{NS}$ & $0.51 \mathrm{NS}$ & $0.72 \mathrm{NS}$ & $2.96 \mathrm{NS}$ & $2.68 \mathrm{NS}$ & $1.09 \mathrm{NS}$ & $0.40 \mathrm{NS}$ \\
\hline$t^{*}$ Condition & 1 & $11.46^{* *}$ & $12.58^{* *}$ & $0.15 \mathrm{NS}$ & $0.34 \mathrm{NS}$ & $0.62 \mathrm{NS}$ & $1.19 \mathrm{NS}$ & $0.24 \mathrm{NS}$ & $0.19 \mathrm{NS}$ & $3.01 \mathrm{NS}$ \\
\hline$t * \mathrm{TR} * \mathrm{C}$ & 3 & $0.32 \mathrm{NS}$ & $1.33 \mathrm{NS}$ & $4.24^{*}$ & $0.93 \mathrm{NS}$ & $0.24 \mathrm{NS}$ & $3.56^{*}$ & $0.80 \mathrm{NS}$ & $0.41 \mathrm{NS}$ & $4.12^{*}$ \\
\hline
\end{tabular}

NS, nonsignificant. $* P<0.05 ; * * P<0.01 ; * * P<0.001$.

positively correlated $(r>0.5)$ with Tween-40 and Tween80, two polymers, phenylethylamine and L-serin, while those incubated under stressed conditions were characterized by a high utilization of glucose-1-phosphate, $N$-acetyl-D-glucosamine and D-cellobiose, three labile components.

\section{Discussion}

Effect of olive mill waste and glyphosate-based herbicide on soil microbial activities

Interestingly, the treatments applied did not induce strong changes in the microbial markers tested. This may differ 

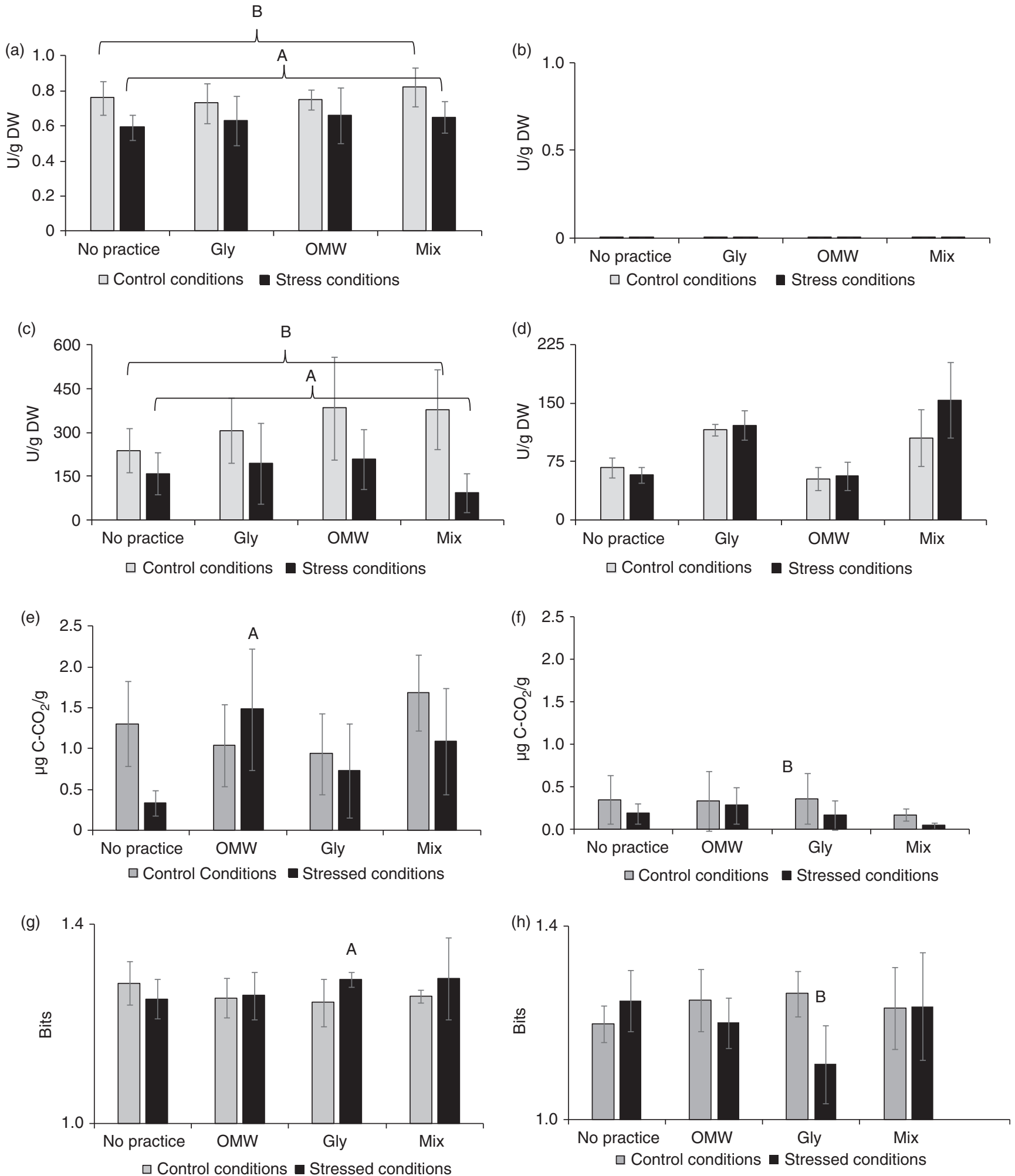

Figure 5 Mean ( \pm standard error, $N=4$ ) tyrosinases (a and b), proteases (c and d), basal respiration (e and f) and catabolic diversity index ( $\mathrm{g}$ and $\mathrm{h}$ ) after the addition of olive mill waste (OMW), glyphosate-based herbicide (Gly), combination of both (Mix) and no practice for T1 (a, c, e, g) and T2 (b, d, f, h). For basal respiration and catabolic diversity index, different uppercase letters represent significant differences between $\mathrm{T} 1$ and $\mathrm{T} 2$ while for tyrosinases and proteases, different uppercase letters represent significant differences at $\mathrm{T} 1$ between both conditions. 


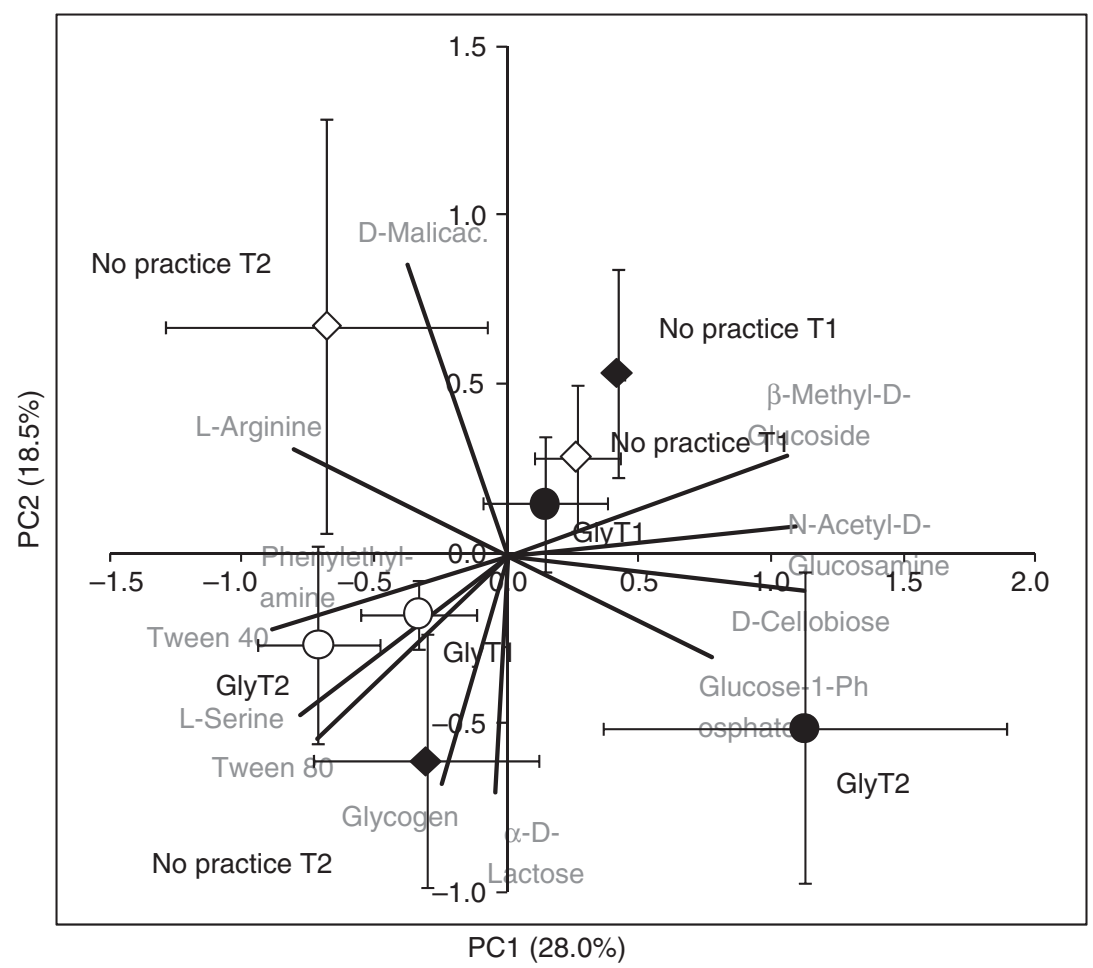

Figure 6 Factorial map $(\mathrm{PC} 1 \times \mathrm{PC} 2)$ obtained from principal component analysis on microbial C-substrate utilization profiles for no practice (diamonds) and for glyphosate-based herbicide (circle) at T1 and T2 after drought stress (black symbols) or without drought stress (white symbols).

from the expected effects of the treatments under field conditions and could be explained by the limited amount of soil and the inadequate imitation of the field environment, which may modify microorganism responses. In addition, this study only represented the possible effects observed for the 10-cm-depth soil, without considering the effects obtained below this surface layer.

Of all the microbial markers, only higher lipases were measured after 3-month incubation under Gly treatment compared with 'no practice', and the reverse trend was observed after 5-month incubation. Addition onto soil of glyphosate-based herbicides can provide a source of labile $\mathrm{C}$, $\mathrm{P}$ or $\mathrm{N}$ for heterotrophic microorganisms (Zabaloy et al., 2008). However, we did not observe any significant change in basal respiration or microbial biomass, indicating that the quantity of herbicide applied onto soil was too low to be considered as a significant $\mathrm{C}$ source. Higher lipase activities measured at T1 may result from the addition of lipids as substrates as Roundup ${ }^{\circledR}$ contains polyoxyethyleneamine (POEA) as surfactant at a concentration of $150 \mathrm{~g} / \mathrm{L}$ (Sawada et al., 1988). POEA derives from tallow, a complex mixture of fatty acids, such as oleic and palmitic acids, which can induce the production of lipases (Meloni et al., 2014). Similar results were obtained after glyphosate-based herbicide addition for enzyme activities such as fluorescein diacetate (FDA) hydrolases (Araújo et al., 2003). Enzymes involved in FDA hydrolysis include lipases and proteases (Caldwell, 2005) and are used as indicators of soil biological activity. On the other hand, glyphosate-based herbicides, including Roundup ${ }^{\circledR}$, are quite rapidly degraded in soil with an estimated half-life of 7-60 days (Giesy et al., 2000). Thus, the decrease in lipases under glyphosate-based herbicide treatment after 5 months may be explained by the short persistence of such herbicide in soils (Accinelli et al., 2005). However, as lipases after 5 months reached a lower level compared with 'no practice', glyphosate-based herbicide addition may have induced a shift in the microbial community as previously reported by Lane et al. (2012), leading to a decrease in microbial activities. Our study revealed differences in catabolic profiles between 'no practice' and Gly treatment. In a similar agronomic context, a similar shift in catabolic profiles was observed after glyphosate-based herbicide addition by Zabaloy et al. (2012) who related those differences to less efficient C-substrate utilization probably due to the deleterious effect of glyphosate on microbial communities.

In our study, OMW amendment did not induce any modifications in soil chemical properties and this may explain the neutral effect of OMW amendment on microbial properties. However, Nasini et al. (2013) indicated that the application of olive mill wastes onto soils of Mediterranean agrosystems, especially in olive groves, could be considered 
as fertilizer as they contain high concentrations of organic matter and nutrients. Many studies have shown a temporary decrease in soil pH (Barbera et al., 2013; Di Bene et al., 2013) and an increase in bulk density, phenol concentration and $\mathrm{C} / \mathrm{N}$ ratio (Di Bene et al., 2013) and consequently, an increase in microbial basal respiration and biomass has been reported (Magdich et al., 2012). We therefore expected to measure a decrease in soil $\mathrm{pH}$ where OMW was applied. The lack of $\mathrm{pH}$ change obtained after the application of OMW treatment may suggest that less phenols and tannins were applied with OMW in this study, as these substances have been found to influence soil acidity (Sahraoui et al., 2013).

While the 'Mix' treatment had an additive effect on lipases at T1, a non-additive synergic effect was observed at T2. Lipases were significantly higher on the 'Mix' treatment compared with both OMW and Gly treatments applied alone. The higher activities suggest that the combination of lipids from OMW (Dermeche et al., 2013) and Roundup ${ }^{\circledR}$ surfactant could have induced an overproduction of lipases, which counteracted the negative effect of the Gly treatment observed at T2. This result may be associated with the shift in catabolic profiles observed between the 'Mix' and Gly treatments at T2. This suggests that the synergic effect obtained for lipases on the 'Mix' treatments may result from a change in microbial communities. Furthermore, our results highlighted the decrease in soil chemical properties, such as $\mathrm{pH}$, at $\mathrm{T} 1$ on the 'Mix' treatment compared with either the OMW or Gly treatment. The Gly treatment may have brought $\mathrm{N}$ and $\mathrm{P}$ into soil, through glyphosate and polyoxyethyleneamine, or enhanced soil inorganic $\mathrm{N}$ availability in the short term (Snapp \& Borden, 2005). An increase in available nutrients would have stimulated microbial biodegradation of soil organic matter and lipids, phenols and tannins from the OMW and the production of small organic acids derived from pyruvate, an end product of glycolysis (Garrett \& Grisham, 2013).

\section{The effects of drying-rewetting cycles on soil microbial activities}

In our study, we applied drying-rewetting cycles mimicking variations in soil moisture under a Mediterranean climate. After a short incubation time (T1), of all enzymes tested, only tyrosinases and proteases decreased after one $\mathrm{D} / \mathrm{Rw}$ cycle, whatever the applied treatment. Transformation of the recalcitrant fraction of organic matter such as phenols is of major importance in $\mathrm{C}$ recycling and here, we found that tyrosinases decreased after one $\mathrm{D} / \mathrm{Rw}$ cycle. As phenoloxidase production is mainly by fungi (Sinsabaugh, 2010) and because others factors (e.g. $\mathrm{N}$ content, $\mathrm{pH}$, seasonal patterns) were controlled in the experiment, a decrease in this specific activity suggested that fungal communities may be particularly sensitive to such hydric stresses. Garcia et al. (1994) showed that protease activities, which are involved in the $\mathrm{N}$ cycle, can be dependent on microbial biomass. Nevertheless, because neither microbial biomass nor basal respiration was significantly affected by one $\mathrm{D} / \mathrm{Rw}$ cycle, the decrease in proteases reported in our study cannot be correlated with the size of microbial community. Variations in extracellular enzyme activities after drying-rewetting events have been extensively studied and contrasting results found. Alarcón-Gutiérrez et al. (2010) showed that a drying-rewetting cycle can decrease soil enzyme activities, which can be partially explained by protein conformational changes and a decrease in substrate diffusion.

Three $\mathrm{D} / \mathrm{Rw}$ cycles also influenced catabolic profiles for the Gly treatment compared with 'no practice'. Here, microbial CLPPs after Gly treatment under control conditions (no stress) were characterized by a high utilization of two polymers which are mainly degraded by fungi. After the $3 \mathrm{D} / \mathrm{Rw}$ cycles, microbial CLPPs were characterized by a high utilization of three labile components. These changes were associated with a lower $\mathrm{CD}$ index, $\mathrm{H}$, in response to the $3 \mathrm{D} / \mathrm{Rw}$ cycles which showed a decrease in the potential of utilization of carbon resources. This result suggested that microbial communities were less resilient to the $3 \mathrm{D} / \mathrm{Rw}$ cycles under glyphosate-based herbicide treatment. Few studies have investigated the effect of water stress on soil microbial community after glyphosate-based herbicide addition. Means \& Kremer (2007) reported that glyphosatebased herbicide application under water stress conditions resulted in lower number of Fusarium spp in soybean cultures. Moreover, while one $\mathrm{D} / \mathrm{Rw}$ event did not induce significant change in basal respiration, two additional $\mathrm{D} / \mathrm{Rw}$ events decreased basal respiration of soils on the OMW treatment. A similar decrease in basal respiration was also observed by Mekki et al. (2009) under Mediterranean climate conditions. This may be explained by a less efficient potential of soil communities to degrade the polyphenols and lipids found in OMW after multiple D/R cycles (Guénon \& Gros, 2015). Mekki et al. (2006) reported that an increase, under favourable conditions, in the fungal-to-bacterial ratio in soils amended with OMW was linked to the catabolism of such compounds. Thus, here, under exacerbated matric stress, fungal communities may have been strongly affected and this may explain the observed decrease in basal respiration after three $\mathrm{D} / \mathrm{Rw}$ cycles.

\section{Conclusion}

Our experimental study suggested that the lack of positive effects of OMW on soil quality reported in literature may due to limitations of the mesocosm-scale method. OMW inputs should be greater than those applied in the field, in order to obtain measurable effects on soil properties. Mixing both OMW and glyphosate-based herbicide treatments counteracted the negative effects of glyphosate-based 
herbicide on lipases and microbial catabolic profiles. On the other hand, after three drying-rewetting cycles, the glyphosate-based herbicide treatment had modified the functional diversity of soil microbial communities. Moreover, OMW treatment decreased microbial respiration and caused a decreased in capacity of microbial communities to degrade the recalcitrant fraction of organic matter. Further studies should investigate the effect of long-term application of these treatments (more than one addition) on soil microbial communities under climate stresses.

\section{Acknowledgements}

This work was supported financially by a PhD grant from the National Council for Scientific Research in Lebanon (CNRSL, Beirut, Lebanon). We would like to thank all the people who helped us in field experiments and provided technical assistance. We are also grateful for the comments and suggestions from two anonymous reviewers who helped to improve the manuscript. The authors declare that they have no conflict of interest.

\section{References}

Accinelli, C., Koskinen, W.C., Seebinger, J.D., Vicari, A. \& Sadowsky, M.J. 2005. Effects of incorporated corn residues on glyphosate mineralization and sorption in soil. Journal of Agricultural and Food Chemistry, 53, 4110-4117.

Alarcón-Gutiérrez, E., Floch, C., Ziarelli, F., Augur, C. \& Criquet, S. 2010. Drying-rewetting cycles and $\gamma$-irradiation effects on enzyme activities of distinct layers from a Quercus ilex L. litter. Soil Biology and Biochemistry, 42, 283-290.

Anderson, J. \& Domsch, K. 1978. A physiological method for the quantitative measurement of microbial biomass in soils. Soil Biology and Biochemistry, 10, 215-221.

Araújo, A.S.F., Monteiro, R.T.R. \& Abarkeli, R.B. 2003. Effect of glyphosate on the microbial activity of two Brazilian soils. Chemosphere, 52, 799-804.

Baldock, J., Oades, J., Waters, A., Peng, X., Vassallo, A. \& Wilson, M. 1992. Aspects of the chemical structure of soil organic materials as revealed by solid-state 13C NMR spectroscopy. Biogeochemistry, 16, 1-42.

Barbera, A.C., Maucieri, C., Cavallaro, V., Iopollo, A. \& Spagna, G. 2013. Effects of spreading olive mill wastewater on soil properties and crops, a review. Agricultural Water Management, 119, 43-53.

Beare, M.H., Neely, C.L., Coleman, D.C. \& Hargrove, W.L. 1990. A substrate-induced respiration (SIR) method for measurement of fungal and bacterial biomass on plant residues. Soil Biology and Biochemistry, 22, 585-594.

Cabrera, A., Cox, L., Spokas, K.U.R.T., Hermosín, M.C., Cornejo, J. \& Koskinen, W.C. 2014. Influence of biochar amendments on the sorption-desorption of aminocyclopyrachlor, bentazone and pyraclostrobin pesticides to an agricultural soil. Science of the Total Environment, 470, 438-443.

Caldwell, B.A. 2005. Enzyme activities as a component of soil biodiversity: a review. Pedobiologia, 49, 637-644.
Dermeche, S., Nadour, M., Larroche, C., Moulti-Mati, F. \& Michaud, P. 2013. Olive mill wastes: biochemical characterizations and valorization strategies. Process Biochemistry, 48, 1532-1552.

Di Bene, C., Pellegrino, E., Debolini, M., Silvestri, N. \& Bonari, E. 2013. Short- and long-term effects of olive mill wastewater land spreading on soil chemical and biological properties. Soil Biology and Biochemistry, 56, 21-30.

Doula, M.K., Moreno-Ortego, J.L., Tinivella, F., Inglezakis, V.J., Sarris, A. \& Komnitsas, K. 2017. Olive mill waste: Recent advances for the sustainable development of olive oil industry. In: Olive mill waste: Recent advances for sustainable management (ed. C.M. Galanakis), pp. 29-56. Elsevier-Academic Press, London, United Kingdom.

Farnet, A.M., Qasemian, L., Goujard, L., Gil, G., Guiral, D., Ruaudel, F. \& Ferre, E. 2010a. A modified method based on $p$ nitrophenol assay to quantify hydrolysis activities of lipases in litters. Soil Biology and Biochemistry, 42, 386-389.

Farnet, A.M., Qasemian, L., Guiral, D. \& Ferré, E. 2010b. A modified method based on arsenomolybdate complex to quantify cellulase activities: application to litters. Pedobiologia, 53, 159-160.

Garcia, C., Hernandez, T. \& Costa, F. 1994. Microbial activity in soils under Mediterranean environmental conditions. Soil Biology and Biochemistry, 26, 1185-1191.

Garland, J.L. \& Mills, A.L. 1991. Classification and characterization of heterotrophic microbial communities on the basis of patterns of community-level sole-carbon-source utilization. Applied and Environmental Microbiology, 57, 2351-2359.

Garrett, R.H. \& Grisham, C.M. 2013. Biochemistry, 5th edn. Brooks/Cole, Cengage Learning, Belmont, CA.

Gaupp-Berghausen, M., Hofer, M., Rewald, B. \& Zaller, J.G. 2015. Glyphosate-based herbicides reduce the activity and reproduction of earthworms and lead to increased soil nutrient concentrations. Scientific Reports, 5, 12886.

Giesy, J.P., Dobson, S. \& Solomon, K.R. 2000. Ecotoxicological risk assessment for Roundup ${ }^{\circledR}$ herbicide. In: Reviews of environmental contamination and toxicology (eds G.W. Ware), pp. 35-120. Springer, New York.

Giorgi, F. \& Lionello, P. 2008. Climate change projections for the Mediterranean region. Global and Planetary Change, 63, 90-104.

Guénon, R. \& Gros, R. 2015. Increasing the maturity of compost used affects the soil chemical properties and the stability of microbial activity along a mediterranean post-fire chronosequence. European Journal of Soil Biology, 66, 1-10.

Haney, R., Senseman, S. \& Hons, F. 2002. Effect of Roundup Ultra on microbial activity and biomass from selected soils. Journal of Environmental Quality, 31, 730-735.

IPCC, 2014. Climate change 2014: Impacts, adaptation, and vulnerability. Part B: regional aspects. In: Contribution of working group II to the fifth assessment report of the intergovernmental panel on climate change (eds. V.R. Barros, C.B. Field, D.J. Dokken, M.D. Mastrandrea, K.J. Mach, T.E. Bilir, M. Chatterjee, K.L. Ebi, Y.O. Estrada, R.C. Genova, B. Girma, E.S. Kissel, A.N. Levy, S. MacCracken, P.R. Mastrandrea \& L.L. White), 688 pp. Cambridge University Press, Cambridge, UK and New York, NY, USA.

Kandeler, E. \& Gerber, H. 1988. Short-term assay of soil urease activity using colorimetric determination of ammonium. Biology and Fertility of Soils, 6, 68-72. 
Ladd, J. \& Butler, J. 1972. Short-term assays of soil proteolytic enzyme activities using proteins and dipeptide derivatives as substrates. Soil Biology and Biochemistry, 4, 19-30.

Lane, M., Lorenz, N., Saxena, J., Ramsier, C. \& Dick, R.P. 2012. The effect of glyphosate on soil microbial activity, microbial community structure, and soil potassium. Pedobiologia, 55, 335342.

Lozano-García, B., Parras-Alcántara, L. \& Del Toro Carrillo de Albornoz, M. 2011. Effects of oil mill wastes on surface soil properties, runoff and soil losses in traditional olive groves in southern Spain. Catena, 85, 187-193.

Magdich, S., Jarboui, R., Rouina, B.B., Boukhris, M. \& Ammar, E. 2012. A yearly spraying of olive mill wastewater on agricultural soil over six successive years: impact of different application rates on olive production, phenolic compounds, phytotoxicity and microbial counts. Science of the Total Environment, 430, 209-216.

Means, N.E. \& Kremer, R.J. 2007. Influence of soil moisture on root colonization of glyphosate-treated soybean by Fusarium species. Communications in Soil Science and Plant Analysis, 38, 1713-1720.

Mekki, A., Dhouib, A. \& Sayadi, S. 2006. Changes in microbial and soil properties following amendment with treated and untreated olive mill wastewater. Microbiological Research, 161, 93-101.

Mekki, A., Dhouib, A. \& Sayadi, S. 2009. Evolution of several soil properties following amendment with olive mill wastewater. Progress in Natural Science, 19, 1515-1521.

Meloni, Z.M., Benfatti, M., Baldo, C., Moreira-Gasparin, F. \& Celligoi, M. 2014. Study of lipase production by a filamentous fungus isolated from soil contaminated with lipid residues. $B M C$ Proceeding, 8, 171.

Nasini, L., Gigliotti, G., Balduccini, M.A., Federici, E., Cenci, G. \& Proietti, P. 2013. Effect of solid olive-mill waste amendment on soil fertility and olive (Olea europaea L.) tree activity. Agriculture, Ecosystems and Environment, 164, 292-297.

Nguyen, D.B., Rose, M.T., Rose, T.J., Morris, S.G. \& Van Zwieten, L. 2016. Impact of glyphosate on soil microbial biomass and respiration: a meta-analysis. Soil Biology and Biochemistry, 92, 5057.

Peri, C. \& Proietti, P. 2014. Olive mill waste and by-products. In: The extra-virgin olive oil handbook (ed. C. Peri), pp. 283-302. John Wiley\& Sons, Ltd, Chichester, UK.

Proietti, P., Federici, E., Fidati, L., Scargetta, S., Massaccesi, L., Nasini, L., Regni, L., Ricci, A., Cenci, G. \& Gigliotti, G. 2015. Effects of amendment with oil mill waste and its derived-compost on soil chemical and microbiological characteristics and olive (Olea europaea L.) productivity. Agriculture, Ecosystems and Environment, 207, 51-60.
Regni, L., Gigliotti, G., Nasini, L., Agrafioti, E., Galanakis, C.M. \& Proietti, P. 2017. Reuse of olive mill waste as soil amendment. In: Olive mill waste: Recent advances for sustainable management (ed. C.M. Galanakis), pp. 97-117. Elsevier-AcademicPress, London, United Kingdom.

Sahraoui, H., Jrad, A. \& Mellouli, H.J. 2013. Épandage des margines sur les sols agricoles: impacts environnementaux microbiologiques. Afrique Science: Revue Internationale des Sciences et Technologie, 8, 97-106.

Saiya-Cork, K., Sinsabaugh, R. \& Zak, D. 2002. The effects of long term nitrogen deposition on extracellular enzyme activity in an Acer saccharum forest soil. Soil Biology and Biochemistry, 34, 1309-1315.

Sawada, Y., Nagai, Y., Ueyama, M. \& Yamamoto, I. 1988. Probable toxicity of surface-active agent in commercial herbicide containing glyphosate. The Lancet, 331, 299.

Siles, J.A., Pérez-Mendoza, D., Ibáñez, J.A., Scervino, J.M., Ocampo, J.A., García-Romera, I. \& Sampedro, I. 2014. Assessing the impact of biotransformed dry olive residue application to soil: effects on enzyme activities and fungal community. International Biodeterioration \& Biodegradation, 89, 15-22.

Sinsabaugh, R.L. 2010. Phenol oxidase, peroxidase and organic matter dynamics of soil. Soil Biology and Biochemistry, 42, 391404.

Snapp, S.S. \& Borden, H. 2005. Enhanced nitrogen mineralization in mowed or glyphosate treated cover crops compared to direct incorporation. Plant and Soil, 270, 101-112.

Sofo, A., Manfreda, S., Fiorentino, M., Dichio, B. \& Xiloyannis, C. 2008. The olive tree: a paradigm for drought tolerance in Mediterranean climates. Hydrology and Earth System Sciences Discussions, 12, 293-301.

Tsiknia, M., Tzanakakis, V.A., Oikonomidis, D., Paranychianakis, N.V. \& Nikolaidis, N.P. 2014. Effects of olive mill wastewater on soil carbon and nitrogen cycling. Applied Microbiology and Biotechnology, 98, 2739-2749.

Zabaloy, M.C., Garland, J.L. \& Gómez, M.A. 2008. An integrated approach to evaluate the impacts of the herbicides glyphosate, 2, 4-D and metsulfuron-methyl on soil microbial communities in the Pampas region, Argentina. Applied Soil Ecology, 40, 1-12.

Zabaloy, M.C., Gómez, E., Garland, J.L. \& Gómez, M.A. 2012. Assessment of microbial community function and structure in soil microcosms exposed to glyphosate. Applied Soil Ecology, 61, 333339.

Zaller, J.G., Heigl, F., Fuess, L. \& Grabmaier, A. 2014. Glyphosate herbicide affects belowground interactions between earthworms and symbiotic mycorrhizal fungi in a model ecosystem. Scientific Reports, 4, 5634. 